\title{
Cell Defense Responses Associated with Localized and Systemic Resistance to Phytophthora parasitica Induced in Tomato by an Arbuscular Mycorrhizal Fungus
}

\author{
C. Cordier, ${ }^{1}$ M. J. Pozo, ${ }^{2}$ J. M. Barea, ${ }^{2}$ S. Gianinazzi, ${ }^{1}$ and V. Gianinazzi-Pearson' \\ ${ }^{1}$ Laboratoire de Phytoparasitologie INRA/CNRS, CMSE-INRA, BV 1540, 21034 Dijon cédex, France; \\ ${ }^{2}$ Estacion Experimental del Zaidin, CSIC, 18008 Granada, Spain \\ Accepted 12 May 1998.
}

\begin{abstract}
The arbuscular mycorrhizal fungus Glomus mosseae is able to confer bioprotection against Phytophthora parasitica in tomato roots. Localized and induced systemic resistance (ISR) have been demonstrated to be involved in pathogen control in mycorrhizal and nonmycorrhizal roots with a split root experimental system. Decreased pathogen development in mycorrhizal and nonmycorrhizal parts of mycorrhizal root systems is associated with accumulation of phenolics and plant cell defense responses. G. mosseae-containing cortical cells in the mycorrhizal tissues are immune to the pathogen and exhibit a localized resistance response with the formation of cell wall appositions reinforced by callose adjacent to intercellular hyphae. The systemically induced resistance in nonmycorrhizal root parts is characterized by elicitation of host wall thickenings containing non-esterified pectins and PR-1a protein in reaction to intercellular pathogen hyphae, and by the formation of callose-rich encasement material around $\boldsymbol{P}$. parasitica hyphae that are penetrating root cells. PR-1a protein is detected in the pathogen wall only in these tissues. None of these cell reactions are observed in nonmycorrhizal pathogen-infected root systems, where disease development leads to host cell death. The cellular and molecular basis of bioprotection by an arbuscular mycorrhizal fungus is discussed in relation to that induced by other nonpathogenic microorganisms.
\end{abstract}

Additional keywords: $\beta-1,3$ glucans, cytomolecular investigation, wall reactions.

The excessive use of chemical inputs to control disease poses an important problem for present-day plant production systems. Research priorities for alternative management practices compatible with sustainable agriculture and the environment include the use of beneficial soil microorganisms. Antagonistic microorganisms like bacteria (Weller 1988; Van Peer et al. 1991; Lemanceau and Alabouvette 1993; Thomashow and Weller 1995, Van Wees et al. 1997) and fungi

Corresponding author: Vivienne Gianinazzi-Pearson; Telephone: 33380-633155; Fax: 333-80-632363; E-mail: gianina@epoisses.inra.fr

This article is in the public domain and not copyrightable. It may be freely reprinted with customary crediting of the source. The American Phytopathological Society, 1998.
(Falk et al. 1996; Larkin et al. 1996) have been frequently reported to have protective effects against soilborne pathogens. Handelsman and Stabb (1996) reviewed the different mechanisms that could contribute to bioprotection in interactions between antagonistic microbes and pathogens as being (i) production of antibiotics, nutrient competition, or parasitism of the pathogen by antagonistic microbes in the rhizosphere and (ii) interactions within plant tissues with the induction of resistance mechanisms. Systemic resistance against pathogens has mainly been reported to be induced in plants by nonpathogenic Pseudomonas spp. (Van Peer et al. 1991; Hoffland et al. 1996, Van Wees et al. 1997), but induced systemic resistance (ISR) was also recently shown against a pathogenic strain of Fusarium oxysporum with an antagonistic, nonpathogenic race of the fungus (Larkin et al. 1996). Research into the cellular and molecular mechanisms underlying ISR caused by nonpathogenic microorganisms has only just begun. Van Wees et al. (1997) have reported that, in Arabidopsis thaliana, activation by $P$. fluorescens of ISR against both the root pathogen F. oxysporum f. sp. raphani and the aerial pathogen Pseudomonas syringae pv. tomato is not associated with the elicitation of pathogenesis-related (PR) protein genes, which characterizes systemic acquired resistance (SAR) induced by plant pathogens (Linthorst 1991). On the other hand, cytological studies on the biocontrol of $F$. oxysporum f. sp. radicislycopersici by Pythium oligandrum in tomato have shown that the restriction of pathogen proliferation is accompanied by induced host defense reactions, characterized by the formation of wall appositions containing callose and the accumulation of phenolic compounds (Benhamou et al. 1997).

Arbuscular mycorrhizal fungi, which form symbiotic associations with a wide range of plant species, are another interesting group of microoorganisms that effectively reduce root disease by a number of soilborne pathogens (Dehne and Schönbeck 1979; Rosendahl 1985; Jalali and Jalali 1991; Bethlenfalvay and Linderman 1992; Linderman 1994; Barea and Jeffries 1995), including Phytophthora spp. (Bärtschi et al. 1981; Guillemin et al. 1994; Cordier et al. 1996; Mark and Cassells 1996; Pozo et al. 1996; Trotta et al. 1996). Different hypotheses have been proposed to explain bioprotection by arbuscular mycorrhizal fungi. These include (i) improvement of plant nutrition and root biomass in mycorrhizal plants, which could contribute to an increased plant tolerance and compensate for root damage caused by a pathogen, (ii) 
changes in root system morphology, (iii) modification of antagonistic microbial populations in the mycorrhizosphere, and (iv) competition between arbuscular mycorrhizal and pathogenic fungi to colonize root tissues, with the possible induction of resistance mechanisms (Azcon-Aguilar and Barea 1996; Baltruschat and Schönbeck 1975; Bethlenfalvay and Linderman 1992; Hooker et al. 1994; Morandi 1996). However, very little is known of the physiological, cellular, or molecular mechanisms that are really active.

In studies of colonization patterns of tomato roots by the mycorrhizal fungus Glomus mosseae and the pathogen Phytophthora parasitica, we previously showed that proliferation of the pathogen is greatly reduced in mycorrhizal root systems of tomato, compared with nonmycorrhizal ones (Cordier et al. 1996). Moreover, we observed that the host cells containing typical haustoria-like arbuscule structures of the mycorrhizal fungus were not infected by $P$. parasitica and that pathogen proliferation was reduced not only in mycorrhizal parts but also in nonmycorrhizal parts of mycorrhizal root systems. Trotta et al. (1996) demonstrated that although improved phosphate nutrition by the arbuscular mycorrhiza may have contributed to reduced damage by $P$. parasitica in tomato (see also Davis and Menge 1980; Graham and Menge 1982), other mechanisms must be involved in the bioprotective effects. Benhamou et al. (1994) have reported that $F$. oxysporum f. sp. chrysanthemi development in mycorrhizal $\mathrm{Ri}$ T-DNAtransformed carrot roots is accompanied by defense-like hostwall reactions and accumulation of phenolic compounds. The present investigations were aimed at elucidating the cytomolecular phenomena underlying bioprotection against $P$. parasitica in G. mosseae-colonized root systems of tomato. We have used a split root system technique to demonstrate that the arbuscular mycorrhizal fungus $G$. mosseae induces systemic resistance against $P$. parasitica in tomato tissues, and we provide evidence that cellular and molecular plant defense reactions are associated with this resistance as well as that of arbuscule-containing cortical cells.

\section{RESULTS}

\section{Induction of systemic resistance to $P$. parasitica by G. mosseae.}

In 5-week-old control plants in which one root compartment was watered with a filtrate of microbes from the mycorrhizal inoculum, inoculation of the other compartment with $P$. parasitica resulted in rapid development of necroses in large parts of the roots (Table 1) and an overall reduction (approximately 39.8\%) in root biomass, 2 weeks after pathogen inoculation. Root damage was associated with an important inter- and intracellular proliferation of the pathogen in nonmycorrhizal tomato roots (Table 1). Tomato plants inoculated with G. mosseae in one compartment, where mycorrhizal colonization developed to over $50 \%$, showed significant decreases in necroses (approximately 74\%) and in intraradical pathogen hyphae (approximately 84\%) in the other compartment inoculated with $P$. parasitica (Table 1). Pathogen development was mainly intercellular in these mycorrhizal plants. Mycorrhizal and nonmycorrhizal halves of the root systems developed similarly and colonization levels by $G$. mosseae were unaffected when plants were challenged with $P$. parasitica (results not shown). In a second experi- ment, in which mycorrhizal colonization was lower in the $G$. mosseae-inoculated root compartment (28.5\% root cortex) before pathogen inoculation, no significant difference was observed in necrosis development or $P$. parasitica proliferation between control and mycorrhizal $P$. parasiticainoculated tomato plants (Table 1).

\section{Cell responses to pathogen infection in nonmycorrhizal tomato plants.}

$P$. parasitica hyphae developing from zoospores at the root surface penetrated roots via epidermal grooves (Fig. 1A and $\mathrm{B})$, and in most cases the fungus directly infected epidermal cells (Fig. 1C). The pathogen proliferated mainly in the root cortex, intra- and intercellularly, and its presence was frequently accompanied by a widening of intercellular spaces. As previously reported (Cordier et al. 1996), the presence of $P$. parasitica caused cytoplasmic disorganization of invaded cells, resulting in their necrosis and that of adjacent, uninfected, cortical cells. Light microscope observations of plant cell reactions to root infection by $P$. parasitica showed that cell death in nonmycorrhizal roots was associated with an increased yellowish autofluorescence, under UV excitation, of intercellular spaces near invaded cells, and of cell walls and contents of both invaded and adjacent, uninfected, cortical cells (Fig. 2A). This indicates an accumulation of phenolic components in these tissues in reaction to $P$. parasitica, which agrees with previous observations of a strong yellow autofluorescence under blue light (see Cordier et al. 1996). Only weak autofluorescence was observed in cortical tissues of control tomato roots (Fig. 2B).

After PATAg reaction, there was no evidence of ultrastructural modifications in plant walls in contact with intercellular hyphae of $P$. parasitica and, when the pathogen penetrated cortical cells, none of the plant cells observed showed any structural reactions to invading hyphae (Fig. 3A). Nonesterified pectins were always detected with JIM5 antibodies in cell walls of tomato roots (Fig. 3B) and there was no significant difference in immunolabeling density (46.2 \pm 7 gold grains $/ \mu \mathrm{m}^{2}$ ) when roots were infected or not by $P$. parasitica, even though the pathogen degraded and disorganized the tissues. PR-1a protein, considered to be part of plant defense reactions to root pathogens (Tahiri-Alaoui et al. 1993), was not

Table 1. Quantification of induced systemic resistance in nonmycorrhizal (NM) root compartments of 5-week-old NM and mycorrhizal (Gm) tomato plants, 2 weeks after challenging with Phytophthora parasitica $(\mathrm{Ph})$

\begin{tabular}{|c|c|c|c|c|c|c|}
\hline \multirow{3}{*}{$\begin{array}{l}\text { Colonization } \\
\text { parameters }\end{array}$} & \multicolumn{6}{|c|}{ Root compartments } \\
\hline & \multicolumn{2}{|c|}{$\begin{array}{l}\text { Nonmycor- } \\
\text { rhizal plants }\end{array}$} & \multicolumn{4}{|c|}{ Mycorrhizal plants } \\
\hline & NM & $\overline{\mathrm{NM}+\mathrm{Ph}}$ & Gm & $\mathrm{NM}+\mathrm{Ph}$ & Gm & $\mathrm{NM}+\mathrm{Ph}$ \\
\hline $\begin{array}{l}\text { Mycorrhizal coloni- } \\
\text { zation (M\%) }\end{array}$ & 0 & 0 & $58.0 \mathrm{a}^{\mathrm{z}}$ & $\mathrm{z} \quad 0$ & $28.5 \mathrm{~b}$ & 0 \\
\hline $\begin{array}{l}\text { Percent root length } \\
\text { with necrosis }\end{array}$ & 0 & $31.9 \mathrm{a}$ & 0 & $8.4 \mathrm{~b}$ & 0 & $30.2 \mathrm{a}$ \\
\hline $\begin{array}{l}\text { Immunoestimated } \\
\text { pathogen hyphae } \\
\text { (no.)/cross section } \\
\text { of roots }\end{array}$ & 0 & $62.5 \mathrm{a}$ & 0 & $10.2 \mathrm{~b}$ & 0 & $62.0 \mathrm{a}$ \\
\hline
\end{tabular}



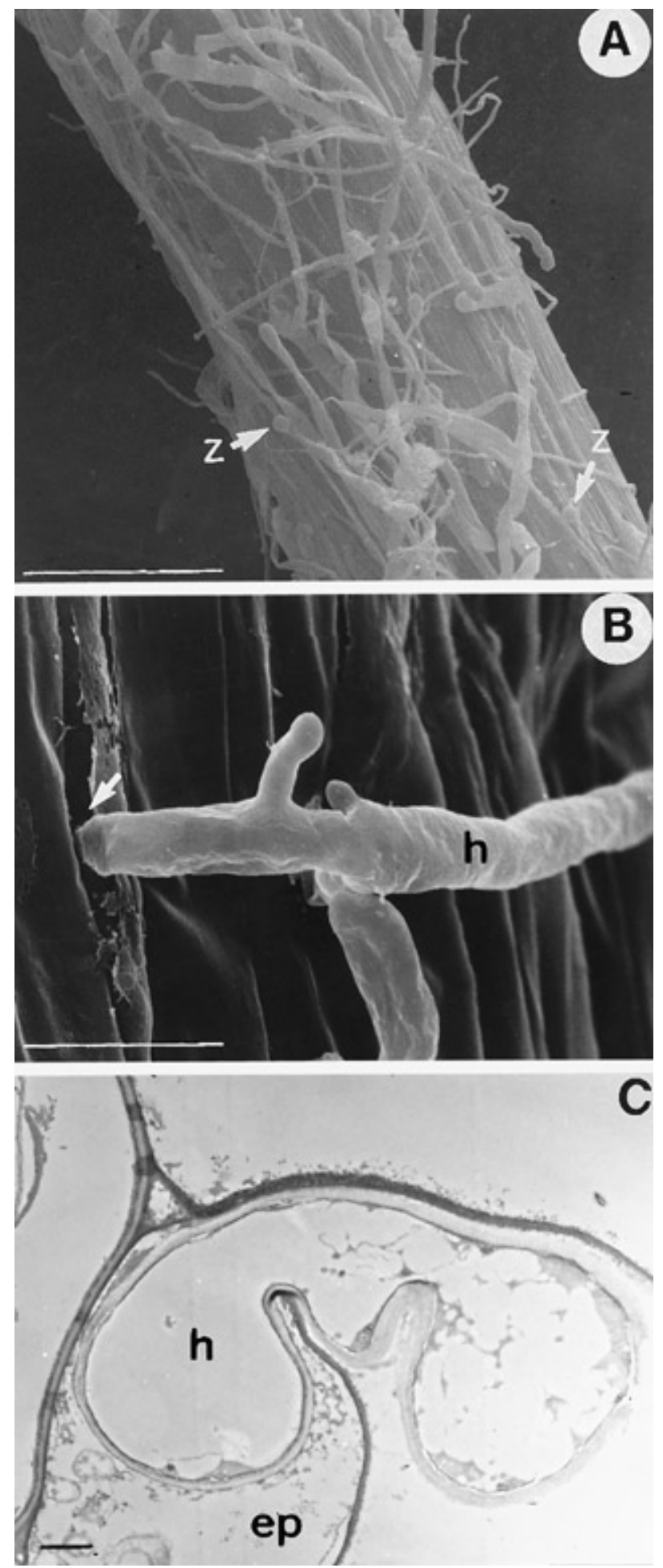

Fig. 1. Scanning (A, B) and transmission (C) electron micrographs of nonmycorrhizal tomato root colonized by Phytophthora parasitica. A, Encysted zoospores (z) germinate to form hyphae (h) on the root surface. B, A hypha (h) penetrates the root via an epidermal groove (arrow). C, Direct infection of an epidermal root cell (ep) by a pathogen hypha (h) (periodic acid-thiocarbohydrazide-silver proteinate [PATAg] reaction). $B a r=(\mathbf{A}) 100 \mu \mathrm{m}$; (B) $10 \mu \mathrm{m}$; (C) $1 \mu \mathrm{m}$ detected by antibodies in nonmycorrhizal tomato roots, whether they were infected or not by $P$. parasitica (not shown). Likewise, $\beta-1,3$ glucans, components of callose, could not be immunolocalized in nonmycorrhizal root systems infected by $P$. parasitica (not shown).

\section{Plant-pathogen interactions in mycorrhizal tissues.}

When mycorrhizal roots were inoculated with $P$. parasitica, the length of necrotic root and the number of pathogen hyphae were significantly $(P \leq 0.05)$ reduced, by 79.2 and $88.5 \%$, respectively, compared with nonmycorrhizal roots. $P$. parasitica development in mycorrhizal tissues was uniquely intercellular and pathogen hyphae were never found in cortical cells colonized by arbuscules of $G$. mosseae. G. mosseae and $P$. parasitica colonized different root regions in most cases so that both fungi were only found together within the same root tissues in 5\% of observed sections. Autofluorescence under UV excitation (lower part of Figure 2C) remained weak in mycorrhizal tissues not colonized by $P$. parasitica, agreeing with previous observations of weak autofluorescence under blue light (Cordier et al. 1996). Pathogen-infected mycorrhizal root tissues fluoresced homogeneously bright yellow under blue light (see also Cordier et al. 1996), but under UV excitation cell walls contained blue-white autofluorescent compounds while intercellular spaces and arbuscule-containing cells had a cream to yellowish autofluorescence (upper part of Figure $2 \mathrm{C}$ ), suggesting that the nature of accumulating components differed in these different tissue domains. Cell walls in the central cylinder of pathogen-infected mycorrhizal roots were characterized by a strong blue autofluorescence under UV excitation together with localized blue-white areas in wall layers of the central vessels (Fig. 2C). Such intense blue autofluorescence was never observed in the central cylinder of nonmycorrhizal or healthy mycorrhizal roots, suggesting the accumulation of additional material in the central cylinder of pathogen-infected mycorrhizal tomato roots.

When $P$. parasitica developed in the cortex, arbusculecontaining cells reacted to the presence of intercellular hyphae of the pathogen by forming wall appositions. These were characterized by PATAg-positive, electron-dense fibrillar zones (Fig. 3C), indicating the presence of $\beta-1,4$ polysaccharides, and nonreactive, electron-translucent zones suggesting the possible presence of callose. Non-esterified pectin accumulated in the interface around intracellular arbuscule trunks in cortical host cells (Fig. 4A) but these molecules could not be localized in the wall appositions formed by arbusculecontaining cells in pathogen-infected mycorrhizal tissues (Fig. 4B), even after pretreatment with $\mathrm{HCl}$ to solubilize components that could interfere with antibody-antigen binding (not shown). In this aspect, they clearly differed from the primary host cell wall (Fig. 4B).

PR-1 related protein was always localized in the interface surrounding arbuscules of $G$. mosseae in host cortical cells (Fig. 4C), but none accumulated in the wall appositions formed by these cells in response to the presence of $P$. parasitica (Fig. 4D). The presence of callose was immunodetected in the host wall appositions of arbuscule-containing cells in pathogen-infected mycorrhizal tissues (Fig. 4E), and was confirmed by the laminarinase treatment that eliminated $\beta-1,3$ glucan antibody labeling (Fig. 4F). 

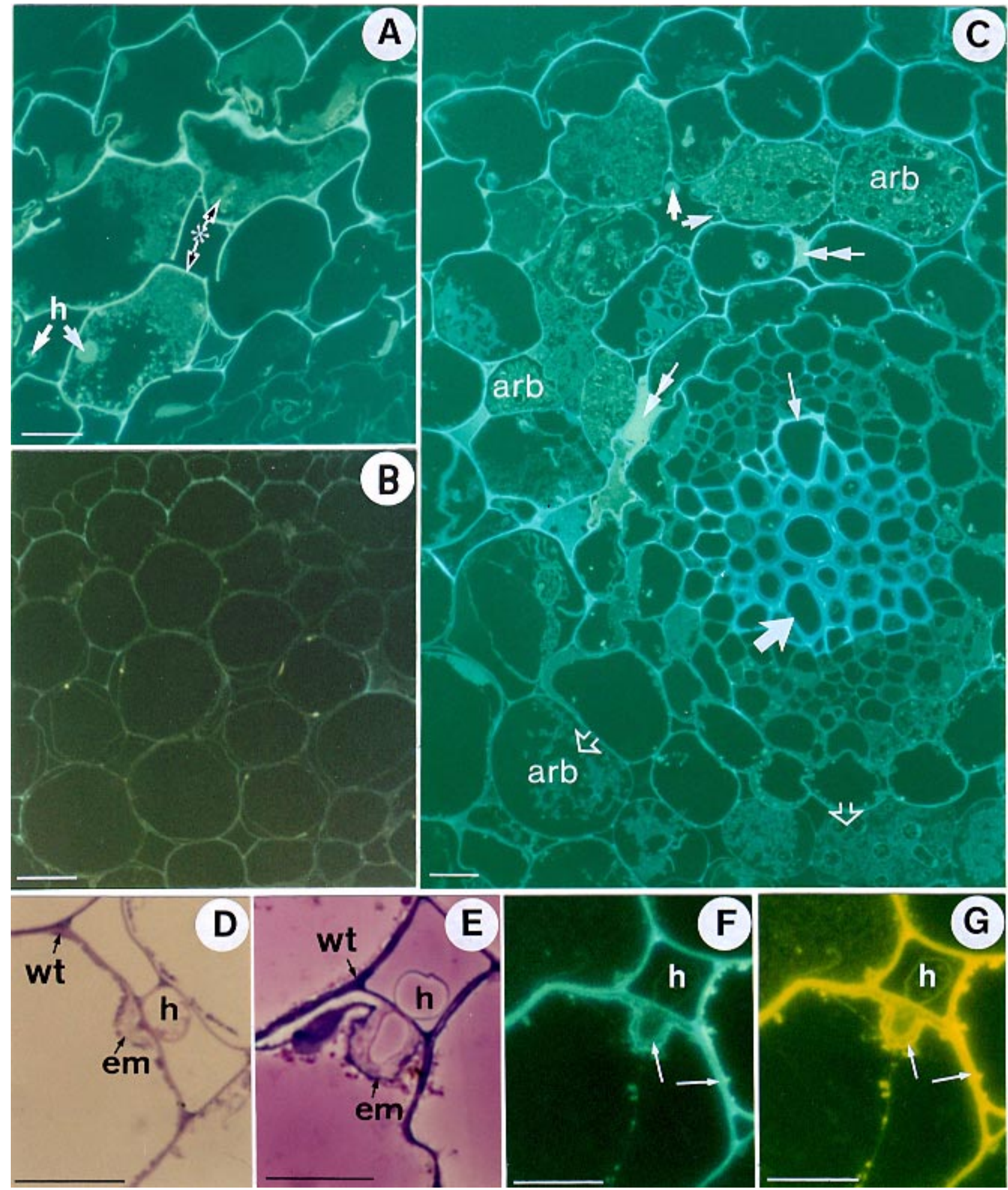

Fig. 2. Semi-thick cross sections of nonmycorrhizal (A, B) and mycorrhizal (C-G) tomato roots infected (A, C-G) or not (B) by Phytophthora parasitica and visualized under UV (A, B, C, F) or blue (G) light, or after staining with toluidine blue (D, E). A, Yellowish autofluorescence is observed in the walls and contents of cortical cells (asterisk) in a nonmycorrhizal root system in response to P. parasitica (h) but (B) not in uninfected roots. C, Mycorrhizal tissues colonized by intercellular pathogen hyphae (h) (upper part of figure) contain autofluorescent compounds that are blue-white in cell walls, cream in intercellular spaces (double headed arrows), and yellowish in arbuscule-containing cells (arb). There is only weak autofluorescence of mycorrhizal tissues in absence of the pathogen (lower part of figure) (open arrows). Cell walls in central cylinder autofluoresce bright blue (large arrow) or blue-white (thin arrow). $\mathbf{D}$ and $\mathbf{E}$, In roots from the nonmycorrhizal compartment of $(\mathbf{C})$, the presence of $P$. parasitica induces formation of wall thickenings (wt) in cells in reaction to intercellular pathogen hyphae (h), and of encasement material (em) when the pathogen manage s to penetrate into root cells. F and $\mathbf{G}$, An increased autofluorescence is associated with the wall thickenings and encasement material seen in $\mathbf{E}$ (arrows). Bar $=10 \mu \mathrm{m}$. 


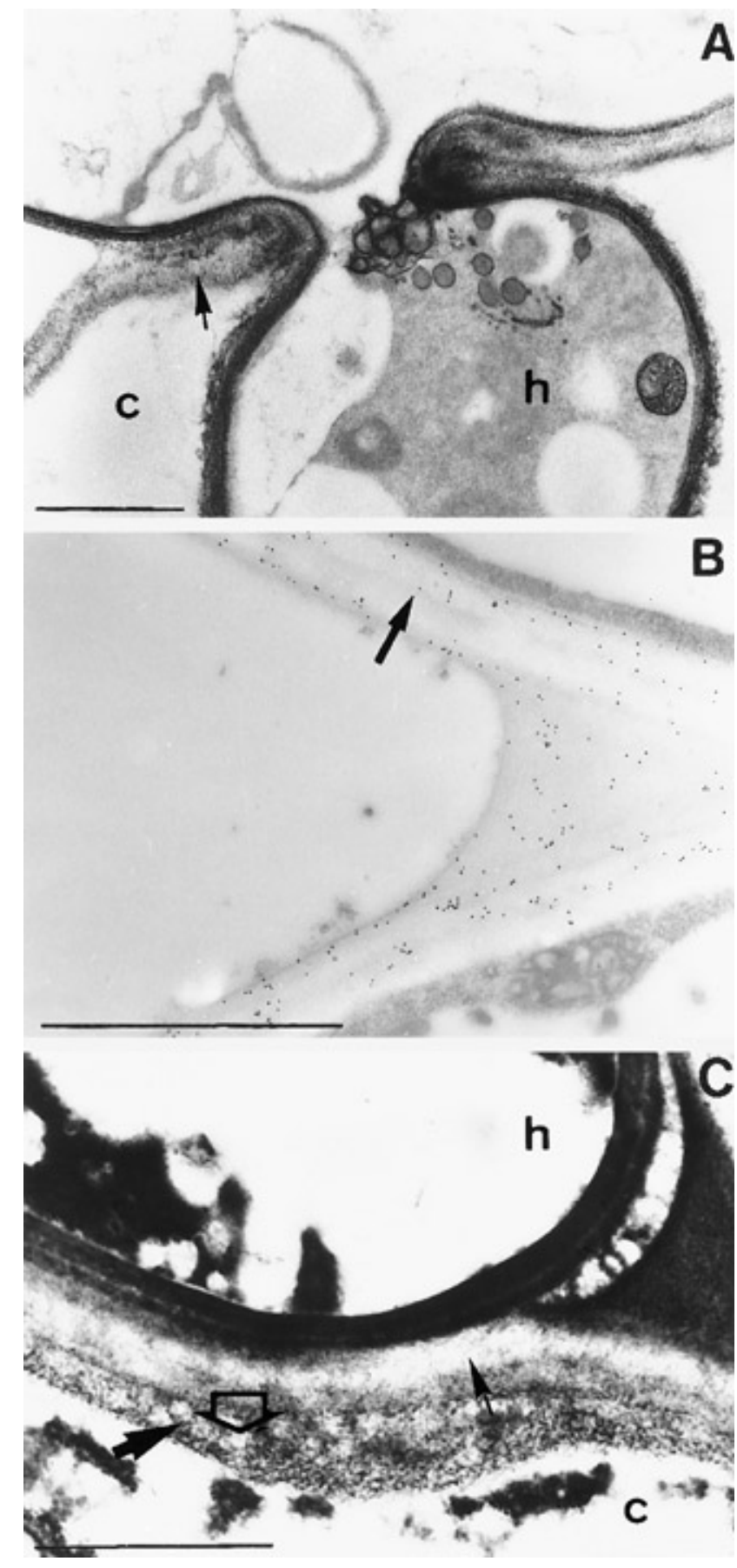

Fig. 3. Periodic acid-thiocarbohydrazide-silver proteinate (PATAg) reaction $(\mathbf{A}, \mathbf{C})$ and immunolocalization of non-esterified pectins (B) in cross sections of nonmycorrhizal $(\mathbf{A}, \mathbf{B})$ and mycorrhizal $(\mathbf{C})$ tomato root systems infected $(\mathbf{A}, \mathbf{C})$ or not $(\mathbf{B})$ by Phytophthora parasitica $(\mathrm{h})$. $\mathbf{A}$, In a nonmycorrhizal root system, the wall of a cortical cell (c) invaded by the pathogen (h) is homogeneously stained (arrow). B, Nonesterified pectins are localized in the primary cortical cell wall of tomato roots (arrow). C, Response of mycorrhizal root tissues to intercellular pathogen hyphae (h) is characterized by formation in arbuscule-containing cortical cells (c) of heterogeneously stained wall appositions (large arrow) with electron translucent (open arrow) zones and adjacent to the primary wall (thin arrow). Bar $=1 \mu \mathrm{m}$.
Cell reactions to $P$. parasitica in tissues

of nonmycorrhizal roots from mycorrhizal plants.

$P$. parasitica developed mainly in intercellular spaces in cortical tissues of nonmycorrhizal parts of mycorrhizal root systems. The presence of the pathogen always induced a thickening of the plant wall (1.8- to 2.3 -fold) in contact with intercellular hyphae (Fig. 5A, B) but there was no elicitation of host wall appositions. Serial cross sections of roots revealed the presence of thicker walls in cells even at some distance from infected intercellular spaces. Occasionally, $P$. parasitica penetrated host cortical cells in nonmycorrhizal parts of the mycorrhizal root system. In these cases, the invaded cell reacted locally by depositing a encasement layer (Figs. 2D and E; 5C; 6D and E) around the penetrating hypha, which was never observed to develop further inside these cells. A strong blue-white (Fig. 2F) and yellow (Fig. 2G) autofluorescence, under UV excitation and blue light, respectively, was associated with the wall thickenings and encasement material formed in reaction to $P$. parasitica hyphae.

The wall thickenings gave a homogeneous PATAg reaction (Fig. 5A) while the encasement material was stained heterogeneously (not shown). There was a pectin component in the wall thickenings (Fig. 5B), which was considerably enriched $\left(91.8 \pm 12\right.$ gold grains $\left./ \mu \mathrm{m}^{2}\right)$, compared with that of the primary cell walls in nonmycorrhizal root systems (see above). Non-esterified pectins were also immunolocalized in the outer part of the encasement material but only after pretreatment with $\mathrm{HCl}$, suggesting that antigenic sites were encrusted in an acid-soluble material (Fig. 5C). Antibodies against PR-1a protein localized corresponding antigens in the plant wall thickenings induced in nonmycorrhizal tissues of a mycorrhizal root system in response to intercellular pathogen hyphae (Fig. 6A), but not in the encasement material. Serial sectioning of material showed a generalized accumulation of PR-1a protein in wall thickenings in diseased tissues, even at a distance of several cells from the pathogen. PR-1a protein antibodies also regularly labeled the wall of $P$. parasitica hyphae growing in nonmycorrhizal parts of mycorrhizal tomato root systems (Fig. 6A), but not hyphae growing in mycorrhizal parts (Fig. 4D) nor mycelium in pure culture (Fig. 6B). $\beta-1,3$ glucans were not found in the wall thickenings of nonmycorrhizal tissues invaded by $P$. parasitica (Fig. 6C), while the encasement material formed around the pathogen in root cells was rich in callose (Fig. 6D and E). The normal $\beta-1,3$ glucan component of walls of $P$. parasitica (Figs. 4E and 6C) was not detected when intracellular pathogen hyphae were surrounded by the encasement material (Fig. 6E).

\section{DISCUSSION}

Results from the split root experimental system developed here demonstrate for the first time that arbuscular mycorrhiza formation induces not only localized but also systemic resistance against $P$. parasitica in tomato roots. The localized resistance of mycorrhizal tissues is seen in the rare occurrence of $P$. parasitica hyphae and their inability to invade arbusculecontaining host cells. The ISR is characterized by large reductions in root damage and in $P$. parasitica development within nonmycorrhizal root tissues of mycorrhizal systems, in comparison to roots of nonmycorrhizal plants. This bioprotection is directly linked to root colonization by the arbuscular 
mycorrhizal fungus since neither a microbial filtrate from the G. mosseae inoculum nor low mycorrhizal levels are sufficient to induce it. The present cytomolecular investigations provide clear evidence that both the localized and the systemic protective effects induced by arbuscular mycorrhiza involve the accumulation of plant defense-related molecules in association with the elicitation of wall reactions in the host roots (Table 2). Although Benhamou et al. (1994) have reported the
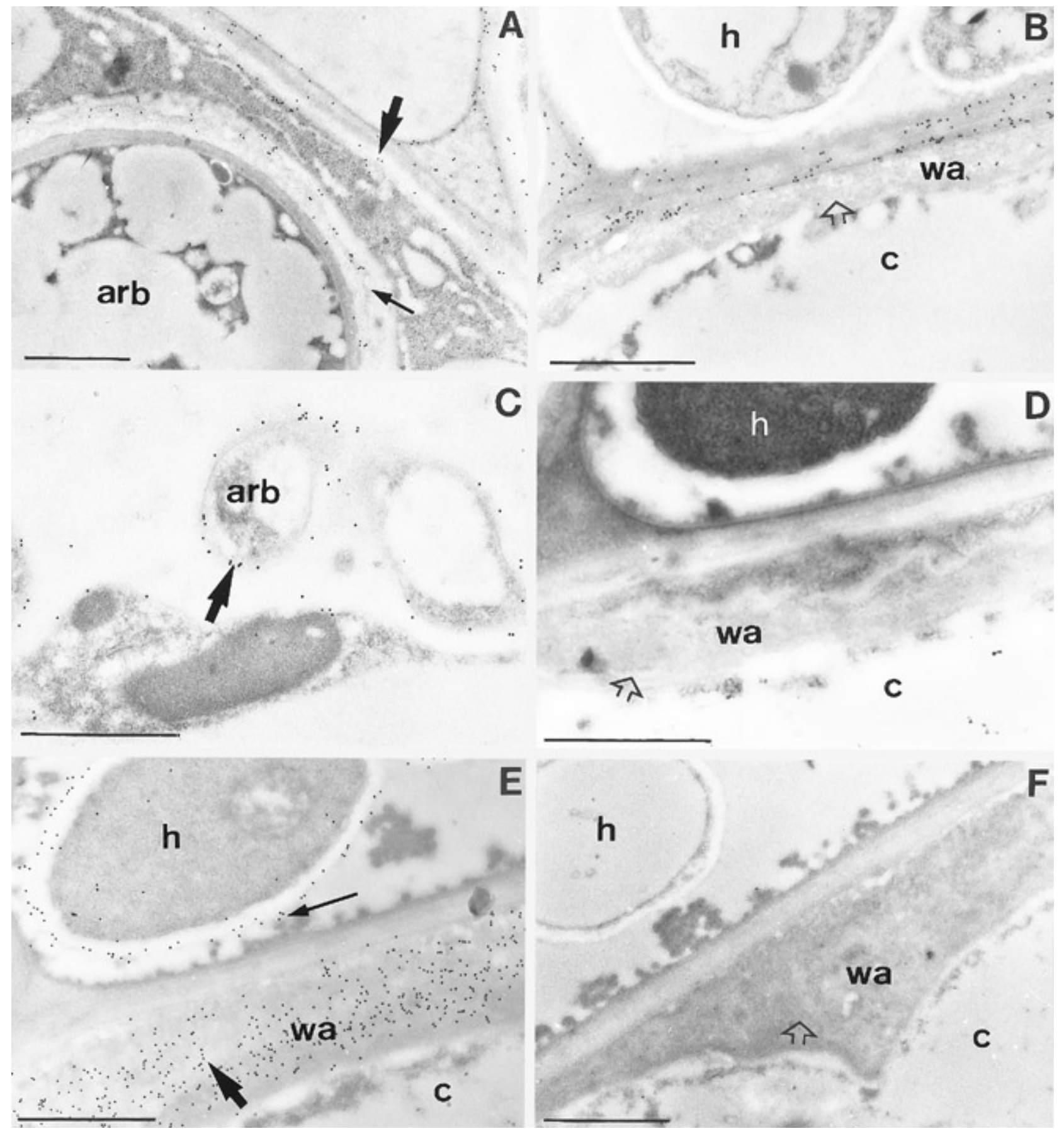

Fig. 4. Immunolocalization of (A, B) non-esterified pectins, $(\mathbf{C}, \mathbf{D})$ PR-1 related protein and $(\mathbf{E}, \mathbf{F}) \beta-1,3$ glucans in cross sections of mycorrhizal tissues of tomato, uninfected $(\mathbf{A}, \mathbf{C})$ or infected $(\mathbf{B}, \mathbf{D}-\mathbf{F})$ by Phytophthora parasitica. A, Non-esterified pectin is immunolabeled in the primary cortical cell wall (large arrow) and in the interface around intracellular arbuscule trunks (arb) (thin arrow). B. In the presence of $P$. parasitica, wall appositions (wa) formed in an arbuscule-containing cell (c) in response to intercellular pathogen hyphae (h) do not contain non-esterified pectin (open arrow). C, PR-1a protein is localized in the interface surrounding arbuscule branches (arb) (arrow) in host cells. D, No immunoreaction is observed for PR-1a protein in the wall apposition (wa) of arbuscule-containing cortical cells (c) (open arrow) formed in response to intercellular pathogen hyphae (h). E, $\beta-1,3$ glucans are localized in a wall apposition (wa) formed in an arbuscule-containing cell (c) (large arrow) in response to intercellular pathogen hyphae (h), indicating presence of callose. The wall of this oomycetous fungus has a typical $\beta-1,3$ component (thin arrow). F, Pretreatment with laminarinase of sections of material from (E) eliminates immunolabeling of callose (open arrow). Bar $=1 \mu \mathrm{m}$. 
presence of callose and phenolics in mycorrhizal-transformed carrot roots challenged with $F$. oxysporum, the present detailed analyses of interactions between $P$. parasitica and mycorrhizal tomato root systems are the first to show that plant cell re-

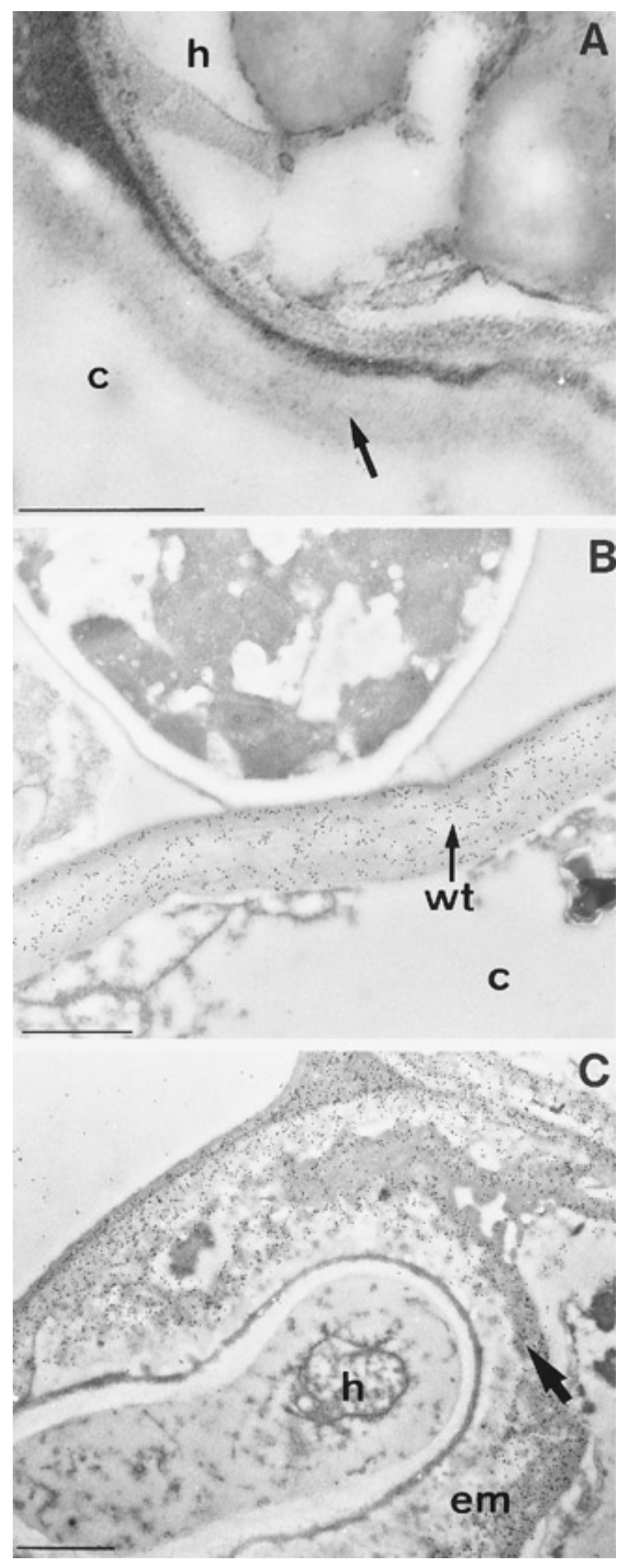

sponses to pathogen development differ in mycorrhizal and nonmycorrhizal tissues.

The resistance of arbuscule-containing cortical cells in mycorrhizal root tissues is characterized by the accumulation of fluorescent compounds and the induction of pectin-free wall appositions that are rich in callose. It is well known that callose reinforces wall barriers produced early during plant defense reactions (Hahn et al. 1989; Collinge et al. 1994). The induced wall appositions in mycorrhizal tissues could therefore contribute to the resistance of arbuscule-containing cortical cells by preventing the penetration of pathogen hyphae from intercellular spaces. Wall modifications were suggested in early work to be involved in the resistance of mycorrhizal onion root segments to Pyrenochaeta terrestris, where restricted pathogen growth within the cortical layer of mycorrhizal roots appeared to be associated with plant cell wall thickenings (Becker and Gerdemann 1977). Similar reinforcement of plant cell walls has likewise been considered to be a facet of bioprotection of tomato roots by P. oligandrum against $F$. oxysporum (Benhamou et al. 1997), although wall appositions did not seem to stop growth of $F$. oxysporum in apical root tissues of cotton (Rodriguez-Galvez and Mendgen 1995). Since we never observed $P$. parasitica hyphae in $G$. mosseae-colonized cells, a possible hypothesis is that the resistance of arbuscule-containing cells is somehow linked to the low priming of defense genes by the presence of the mycorrhizal fungus in these cells (Gianinazzi 1991; GianinazziPearson et al. 1995; Gianinazzi-Pearson 1996). In fact, the observation in tomato that defense-related PR-1 protein accumulates around arbuscules has also been reported for mycorrhizal tobacco and pea roots (Gianinazzi and GianinazziPearson 1992; Gollotte et al. 1994), and transcripts encoding other defense-related molecules like phenylalanine ammonia lyase, chalcone synthase (Harrison and Dixon 1994), and chalcone isomerase (Lambais and Mehdy 1993) have similarly been found to accumulate in arbuscule-containing cells in other plants. Direct antagonism between the pathogenic and symbiotic fungi in mycorrhizal tissues cannot, however, be excluded as an additional mechanism since hyphae of the two fungi were only occasionally found growing together in the same intercellular spaces in the cortex.

The systemic resistance of nonmycorrhizal parts of a mycorrhizal root system is characterized by the elicitation of host wall thickenings adjacent to intercellular $P$. parasitica hyphae and of a papilla-like structure in root cells invaded by the pathogen. The response to $P$. parasitica in these tissues is associated with an accumulation of PR-1a protein in the cell wall thickenings, as has been reported to occur during resistance reactions of tobacco roots to the pathogen Chalara ele-

Fig. 5. Periodic acid-thiocarbohydrazide-silver proteinate (PATAg) reaction (A) and immunolocalization of non-esterified pectin $(\mathbf{B}, \mathbf{C})$ in cross sections of nonmycorrhizal parts of mycorrhizal tomato root systems infected by Phytophthora parasitica. A, Response to intercellular pathogen hyphae (h) is characterized by formation of homogeneous PATAg-positive wall thickenings, indistinguishable from the primary wall of cortical cells (c) (arrow). B and C, Non-esterified pectin is localized (B) in the wall thickening (arrow) of cells (c) in contact with an intercellular pathogen hypha, and (C) after pretreatment with $\mathrm{HCl}$ in the outer layer (arrow) of encasement material (em) surrounding the invading pathogen (h). Bar $=1 \mu \mathrm{m}$. 
gans (Tahiri-Alaoui et al. 1993). There is evidence in plantpathogen interactions that PR proteins are associated with systemic disease resistance since they accumulate during the expression of SAR (Ryals et al. 1996). The presence of PR-1a protein in the wall reactions of the nonmycorrhizal parts of mycorrhizal tomato roots may somehow be linked to the systemic resistance in pathogen-challenged mycorrhizal roots. Overexpression of the PR-1a encoding gene in tobacco has been reported to increase resistance to the pathogen $P$. parasitica var. nicotianae, and proteins of the PR-1 group can have an antifungal activity against Oomycetes (Alexander et al. 1993a, 1993b; Niderman et al. 1995). Accumulation of PR-1a related protein in the nonmycorrhizal parts of mycorrhizal tomato roots and its association with the hyphae of $P$. parasitica only in these tissues may, consequently, indicate a role of this type of protein in controlling the oomycetous pathogen in the

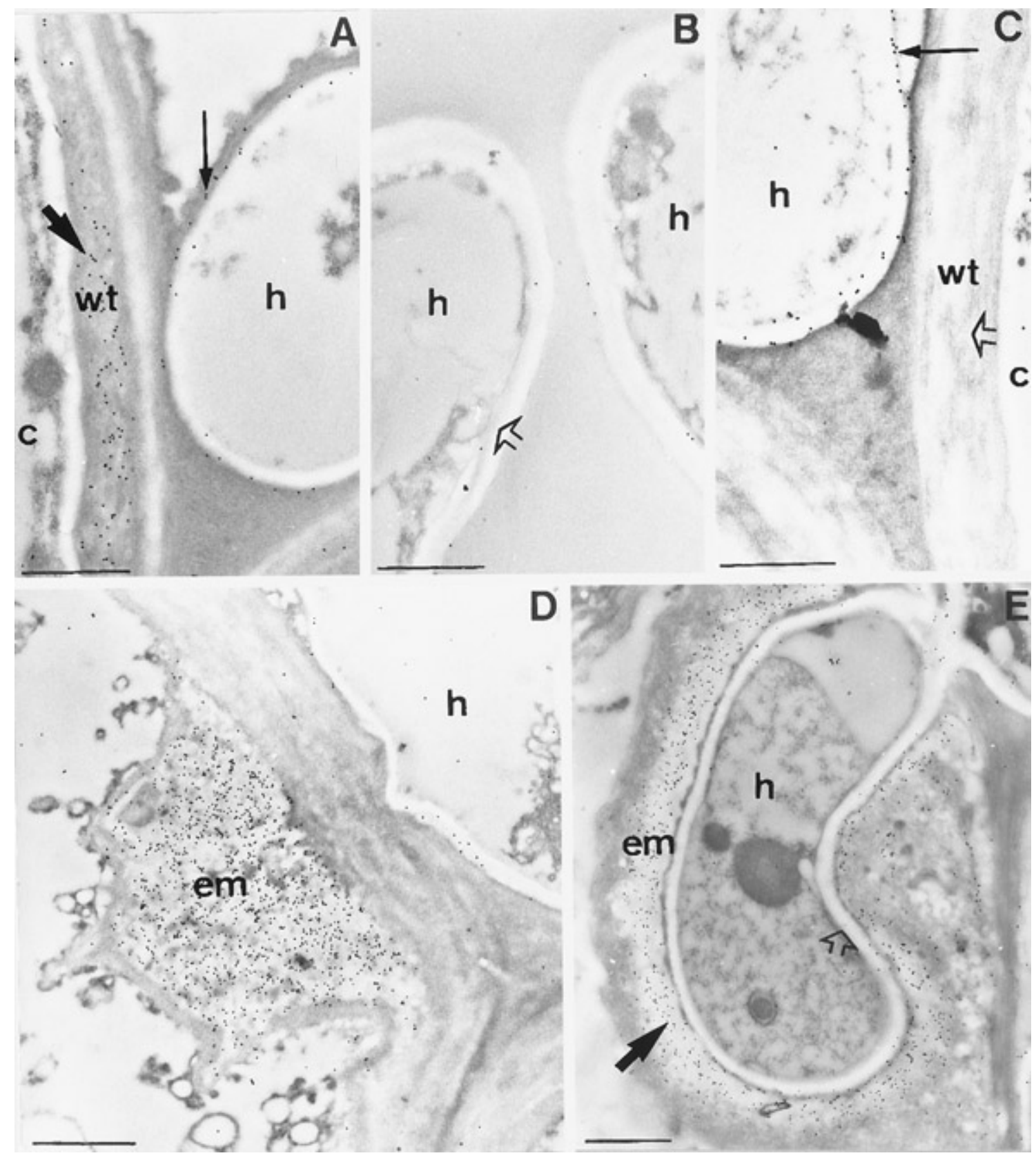

Fig. 6. Immunodetection of PR-1a protein (A, B, C) and $\beta-1,3$ glucans $(\mathbf{D}, \mathbf{E})$ in cross sections of nonmycorrhizal roots of a mycorrhizal tomato root system infected by Phytophthora parasitica $(\mathbf{A}, \mathbf{C}, \mathbf{D}, \mathbf{E})$ and of $P$. parasitica mycelium in pure culture (B). A, PR-1a protein accumulates in wall thickenings (wt) (arrow) formed in cortical cells (c) of nonmycorrhizal tissues in response to an intercellular P. parasitica hypha (h), and over walls of the pathogen (thin arrow). B, No immunolabeling is observed in pathogen mycelium (open arrow) in pure culture. $\mathbf{C}, \beta-1,3$ glucan antibodies do not label the wall thickenings (wt) (open arrow) of a cortical cell (c) in contact with an intercellular pathogen hypha (h). $\beta-1,3$ glucans are observed in the wall of the pathogen (thin arrow). D, Encasement material (em) formed at site of pathogen penetration (h) is rich in $\beta-1,3$ glucans. E, Inner layer of material encasing (em) an intracellular fungal hypha (h) in a cortical cell contains a $\beta-1,3$ component (arrow). Immunolabeling is absent from fungal wall (open arrow). Bar $=1 \mu \mathrm{m}$. 
roots. There are contradictory results concerning the implication of PR proteins in systemic resistance induced by other nonpathogenic microorganisms. PR protein genes are not expressed during ISR induced by $P$. fluorescens WCS417r in radish or Arabidopsis thaliana (Hoffland et al. 1996; Van Wees et al. 1997), while PGPR (plant growth-promoting rhizobacteria) strains with known ISR activity in tomato and cucumber activate the PR-1a in transgenic tobacco plants (Park et al. 1997). However, Maurhofer et al. (1994) suggested that the increased expression of a PR-1 gene during ISR by a $P$. fluorescens strain in tobacco is not directly linked to ISR but rather results from an overall plant stress following $P$. fluorescens infection. Consequently, the extent to which ISR and SAR may be based on common molecular mechanisms remains an open question.

The synthesis of callose-rich encasement material in the form of papillae around $P$. parasitica in invaded host cells is again a phenomenon that is typically related to induced resistance to pathogens in plants (Hahn et al. 1989; Hammond-Kosack and Jones 1996). It could be that the papilla-like structures act as a physical barrier to $P$. parasitica colonization, since the pathogen does not develop further within these cells. However, calloserich encasements can be formed around intracellular fungal pathogens when they have been killed by heat, fungicides, or other means (Skalamera and Heath 1996), so that it is also possible that inhibition of intracellular proliferation of $P$. parasitica in mycorrhizal tomato is due to other, as yet unidentified, plant factors. The fact that the $\beta-1,3$ glucan component disappears from walls of $P$. parasitica as hyphae become surrounded by the encasement papillae does suggest some sort of plant action on pathogen wall metabolism that does not occur when pathogen hyphae colonize cells of nonmycorrhizal tomato root systems (see also Gollotte et al. 1997).

None of the above plant reactions observed in mycorrhizal tomato roots occur in nonmycorrhizal pathogen-infected root systems, where the only striking modification with disease development is a strong yellowish autofluorescence under UV excitation and blue light (Cordier et al. 1996), indicating the accumulation of phenolic components linked to cell necrosis in the invaded tissues. The autofluorescence that is associated with resistance of arbuscule-containing cortical tissues in $P$.

Table 2. Presence (+) or absence (-) of molecular cell responses to Phytophthora parasitica $(\mathrm{Ph})$ in mycorrhizal and nonmycorrhizal tomato root systems

\begin{tabular}{|c|c|c|c|c|c|c|c|c|}
\hline \multirow[b]{2}{*}{ P. parasitica } & \multicolumn{2}{|c|}{$\begin{array}{c}\text { Autofluo- } \\
\text { rescence }\end{array}$} & \multicolumn{2}{|c|}{$\begin{array}{l}\text { PR-1a } \\
\text { related } \\
\text { protein }\end{array}$} & \multicolumn{2}{|c|}{ Callose } & \multicolumn{2}{|c|}{$\begin{array}{c}\text { Non- } \\
\text { esterified } \\
\text { pectins }\end{array}$} \\
\hline & \multicolumn{8}{|c|}{$-\mathbf{P h}+\mathbf{P h}-\mathbf{P h}+\mathbf{P h}-\mathbf{P h}+\mathbf{P h}-\mathbf{P h}+\mathbf{P l}$} \\
\hline \multicolumn{9}{|l|}{ Mycorrhizal root systems } \\
\hline \multicolumn{9}{|c|}{ Arbuscule-containing tissues } \\
\hline Wall & - & + & - & - & - & - & + & + \\
\hline Wall apposition & $\mathrm{NP}^{\mathrm{z}}$ & + & NP & - & NP & + & NP & - \\
\hline Cell contents & - & + & + & + & - & - & + & + \\
\hline \multicolumn{9}{|l|}{ Nonmycorrhizal tissues } \\
\hline Wall thickening & NP & + & NP & + & $\mathrm{NP}$ & - & NP & + \\
\hline Encasement material & NP & + & NP & - & NP & + & NP & + \\
\hline Cell contents & - & + & - & - & - & - & - & - \\
\hline \multicolumn{9}{|c|}{ Nonmycorrhizal root systems } \\
\hline Wall & - & + & - & - & - & - & + & + \\
\hline Cell contents & - & + & - & - & - & - & - & - \\
\hline
\end{tabular}

${ }^{\mathrm{z}}$ Not present in the system. parasitica-infected mycorrhizal roots is of a different nature. The blue-white and pale cream autofluorescence of cell walls and intercellular spaces, respectively, under UV excitation suggests the presence of other components while the yellowish autofluorescence of arbuscule-containing cells could reflect compounds similar to those accumulating in pathogeninfected nonmycorrhizal tissues. The blue-white and strong blue autofluorescence of the central cylinder in pathogeninfected mycorrhizal roots may be related to a greater lignification in mycorrhizal roots, which could further contribute to reducing spread of $P$. parasitica in vascular tissues (Cordier et al. 1996). Daft and Okusanya (1973) have previously reported the effect of mycorrhiza in increasing lignification of the xylem in the aerial parts of tomato and petunia plants. Further, more detailed, analyses are necessary to identify the nature of these fluorescing compounds in mycorrhizal and nonmycorrhizal root tissues in order to better assess their eventual implication in bioprotection.

In conclusion, the induction of plant wall defense responses reflects the activation of molecular mechanisms during bioprotection against $P$. parasitica induced by arbuscular mycorrhiza in tomato. The cell wall modifications associated with localized resistance and the papilla formation characterizing systemic resistance to $P$. parasitica in mycorrhizal tomato root systems are reminiscent of the rapid plant defense responses to pathogens observed in incompatible interactions (Collinge et al. 1994; Hammond-Kosack and Jones 1996). The link between the localized and the systemic resistance is not understood. However, Phytophthora spp. produce elicitins that are inducers of plant defense mechanisms (Ricci et al. 1992; Bonnet et al. 1994), and it cannot be excluded that the elicitin parasiticein produced by $P$. parasitica could be active in interactions in mycorrhizal tomato roots. Immunocytochemical investigations have shown that this fungal molecule is released around intercellular hyphae of the pathogen but only in mycorrhizal tissues (C. Cordier, unpublished results), so that it could be a putative signal in localized resistance. As far as the induction of defense responses in pathogen-infected nonmycorrhizal parts of mycorrhizal root systems is concerned, this must involve a specific, mycorrhiza-induced, mobile signal. Identification of such a signal, which could have a role analogous to salicylic acid or systemin in plant-pathogen interactions (Ryals et al. 1996), will open new horizons for understanding the molecular basis of bioprotection against fungal pathogens in mycorrhizal roots, and for identifying plant genes involved.

\section{MATERIAL AND METHODS}

\section{Plant material and growth conditions.}

Root systems of tomato seedlings (Lycopersicon esculentum Mill. var. Earlymech) were inoculated with Glomus mosseae (Nicol. \& Gerd.) Gerdemann and Trappe (BEG 12) and/or Phytophthora parasitica (isolate 201, kindly provided by P. Bonnet, INRA, Antibes, France) in disinfected (gammairradiated) soil and plants grown as previously described by Cordier et al. (1996).

\section{Split root system to analyze systemic effects of $G$. mosseae on root infection by $P$. parasitica.}

Twelve-day-old tomato seedlings were transplanted into two closely joined culture pots, containing $400 \mathrm{~g}$ of soil, by 
separating their primary and first secondary roots through a 1.5-cm-long hole communicating between the upper half of the two pot compartments. In control plants without inoculation with $G$. mosseae, one compartment was watered with a filtered water suspension (1:1, wt/vol) (Whatman no. 1) of $G$. mosseae inoculum to introduce associated microorganisms. In G. mosseae-inoculated plants, inoculum consisting of mycorrhizal root fragments of leek (Cordier et al. 1996) was placed in the planting hole of one pot compartment at the time of transplantation. After 3 weeks' growth, half the plants from each treatment were inoculated with 20,000 zoospores of $P$. parasitica, obtained according to Cordier et al. (1996), in one compartment of each root system. Pots were filled with grit from the communicating hole to the top to prevent $G$. mosseae from growing from one compartment to the other. Plants were harvested 2 weeks after pathogen inoculation and percent root length with necroses was estimated. Pathogen hyphae within root tissues were immunoquantified (Cordier et al. 1996), and arbuscular mycorrhizal colonization was evaluated as the percentage of root system cortex with fungal structures (M\%), after $\mathrm{KOH}$ digestion and trypan blue staining (Phillips and Hayman 1970) as described by Trouvelot et al. (1986). The experiment was conducted three times with seven replicates per treatment. Data were analyzed statistically with the StatITCF program (analysis of variance, ANOVA; ITCF, Paris) and significant differences were calculated by the NewmanKeul's test at $P \leq 0.05$.

\section{Cytological observations.}

Root fragments for scanning electron microscopy were sampled from tomato plants inoculated with $P$. parasitica, fixed $2 \mathrm{~h}$ in $2 \%$ glutaraldehyde at room temperature and dehydrated through a graded ethanol series (30 to 100\%) followed by $100 \%$ acetone for critical point drying. Samples were sputter coated with a thin gold layer and observed with a Jeol $35 \mathrm{CF}$ scanning electron microscope at $30 \mathrm{kV}$.

For transmission electron microscopy, fragments of nonmycorrhizal or mycorrhizal roots inoculated or not with $P$. parasitica were fixed overnight at $4{ }^{\circ} \mathrm{C}$ in $2 \%$ glutaraldehyde in 0.1 $\mathrm{M}$ cacodylate buffer, $\mathrm{pH} 7.2$, and dehydrated through a graded ethanol series. Samples white in color, indicating healthy root tissue, or with a yellow/brown aspect, suggesting possible necrotic zones caused by the pathogen, were low-temperature embedded $\left(-15^{\circ} \mathrm{C}\right)$ in LR White resin (Gianinazzi and Gianinazzi-Pearson 1992). Three plants were harvested for cytological studies for each treatment, and samples of 13 root fragments were taken at comparable positions from the different root systems. Observations were made on all cells of serial cross sections repeated in four different positions for each fragment. Ultrastructural aspects of cell reactions to $P$. parasitica in nonmycorrhizal and G. mosseae-colonized tomato roots were examined in thin $(90 \mathrm{~nm})$ sections after reaction with periodic acid-thiocarbohydrazide-silver proteinate (PATAg) to localize $\beta-1,4$ and 1,6 polysaccharides (Thiery 1967).

\section{Light microscopy.}

Phenolic material was localized by autofluorescence under blue light (excitation filter: 450 to $500 \mathrm{~nm}$; barrier filter: 515 to $560 \mathrm{~nm}$ ) (Fernandez and Heath 1986; Cordier et al. 1996) or UV excitation (excitation filter: 340 to $380 \mathrm{~nm}$; barrier fil- ter: $425 \mathrm{~nm}$ ) (Jahnen and Hahlbrock 1988) or by staining with toluidine blue (Feder and O'Brien 1968) in semi-thick sections of resin-embedded root fragments.

\section{Immunocytochemical studies.}

Ultrathin sections of LR White embedded root samples were prepared for immunocytochemical analyses by the indirect immunogold-labeling technique described by Gianinazzi and Gianinazzi-Pearson (1992). Polyclonal antibodies raised against Phytophthora megasperma f. sp. glycinea (kindly provided by Elmon Schmelzer, Max-Planck-Institute, Germany) were used to immunoquantify $P$. parasitica hyphae within root sections (Cordier et al. 1996). Non-esterified pectins were localized with rat monoclonal antibodies (AFRC JIM5, kindly provided by the John Innes Centre, Great Britain) (Knox et al. 1990) diluted 1:50. PR-1a protein was detected with mouse monoclonal antibodies diluted 1:10 (kindly provided by the Institute of Arable Crops Research, Great Britain), and $\beta-1,3$ glucans with specific mouse monoclonal antibodies raised against $\beta-1,3$ glucopyranose polymers (Biosupplies Australia, Parkville, Victoria, Australia), diluted 1:1000. For JIM5 antibodies, cross sections were also pretreated $1 \mathrm{~h}$ with $0.1 \mathrm{M} \mathrm{HCl}$ to increase access to antigens that could be covered by other components. For all antibodies, sections were incubated overnight in saline Tris buffer $\mathrm{pH} 7.4$ containing $0.05 \%$ Tween 20 and $1 \%$ bovine serum albumin at $4^{\circ} \mathrm{C}$ and controls were performed by omitting primary antibodies. For $\beta-1,3$ glucans, a control was also performed by pretreating sections overnight with $500 \mathrm{mg} \mathrm{ml}^{-1}$ laminarinase (Sigma, St. Quentin Fallavier, France), a specific $\beta-1,3$ glucanase, as advised by the supplier. Primary antibody binding was localized by incubating sections $1 \mathrm{~h}$ with corresponding gold $(15 \mathrm{~nm})$-labeled secondary antibodies (Biocell, TEBU, Le Perray en Yvelines, France), diluted 1:20. Sections were contrasted with aqueous uranyl acetate. All structural observations were performed with a Hitachi 600 electron microscope at $75 \mathrm{kV}$.

\section{Quantification of immunolabeling.}

For JIM5 antibodies, $\times 30,000$ micrographs were used to estimate the number of gold particles $\cdot \mu \mathrm{m}^{-2}$ over primary cell walls of root from nonmycorrhizal root systems inoculated or not with $P$. parasitica and over primary cell walls, wall appositions, and wall thickenings formed in response to intercellular pathogen hyphae in $P$. parasitica-infected mycorrhizal root systems. Gold particles were counted within a 5- $\mu \mathrm{m}$ zone along cell walls for each micrograph. Data were analyzed statistically with the Stat-ITCF program (ANOVA) and significant differences were calculated by the Newman-Keul's test at $P \leq 0.05$.

\section{ACKNOWLEDGMENTS}

This work was supported by a European AIR Project (no. 3-CT940809). We are very grateful to Michelle Bride and Robert Parisotto, Franche Comté University (France), for their help with scanning electron microscope observations, and to Josette Bonnefoy and Christine Arnould for technical assistance.

\section{LITERATURE CITED}

Alexander, D., Glascock, C., Pear, J., Stinson, J., Ahl-Goy, P., Gut-Rella, M., Goodman, R. M., and Ryals, J. 1993a. Systemic acquired resis- 
tance in tobacco: Use of transgenic expression to study the functions of pathogenesis-related proteins. Pages 527-533 in: Advances in Molecular Genetics of Plant-Microbe Interactions. Vol 3. E. W. Nester and D. P. S. Verma, eds. Kluwer Academic, Dordrecht, The Netherlands.

Alexander, D., Goodman, R. M., Gut-Rella, M., Glascock, C., Weyman, K., Friedrich, L., Maddox, D., Ahl-Goy, P., Luntz, T., Ward, E., and Ryals, J. 1993b. Increased tolerance to two oomycete pathogens in transgenic tobacco expressing pathogenesis-related protein 1a. Plant Biol. 90:7327-7331.

Azcon-Aguilar, C., and Barea, J. M. 1996. Arbuscular mycorrhizas and biological control of soil-borne plant pathogens - an overview of the mechanisms involved. Mycorrhiza 6:457-464.

Baltruschat, M., and Schönbeck, F. 1975. The influence of endotrophic mycorrhiza on the infestation of tobacco by Thielaviopis basicola. Phytopathol. Z. 84:172-188.

Barea, J. M., and Jeffries, P. 1995. Arbuscular mycorrhizas in sustainable soil plant systems. Pages 521-559 in: Mycorrhizae Structure and Function, Molecular Biology and Biotechnology. B. Hock and A. Varma, eds. Springer-Verlag, Berlin.

Bärtschi, H., Gianinazzi-Pearson, V., and Vegh, I. 1981. Vesiculararbuscular mycorrhiza formation and root-rot disease (Phytophthora cinnamomi Rands) development in Chamaecyparis lawsoniana (Murr.) Parl. Phytopathol. Z. 102:213-218.

Becker, W. N., and Gerdemann, J. W. 1977. The resistance of vesiculararbuscular onion mycorrhizae to Pyrenochaeta terrestris. Page 1 in: Abst. No. Am. Conf. Mycorrhiza, 3rd. D. H. Marx, ed.

Benhamou, N., Fortin, J. A., Hamel, C., St.-Arnaud, M., and Shatilla, A. 1994. Resistance responses of mycorrhizal Ri T-DNA-transformed carrot roots to infection by Fusarium oxysporum f. sp. chrysanthemi. Phytopathology 84:958-968.

Benhamou, N., Rey, P., Chérif, M., Hockenhull, J., and Tirilly, Y. 1997. Treatment with the mycoparasite Pythium oligandrum triggers induction of defense-related reactions in tomato roots when challenged with Fusarium oxysporum f. sp. radicis-lycopersici. Phytopathology 87: 108-122.

Bethlenfalvay, G. J., and Linderman, R. G. 1992. Mycorrhizae in sustainable agriculture. Spec. Pub. No. 54. American Society of Agronomy, Madison, WI.

Bonnet, P., Lacourt, I., Venard, P., and Ricci, P. 1994. Diversity in pathogenicity to tobacco and in elicitin production among isolates of Phytophthora parasitica. J. Phytopathol. 141:25-37.

Collinge, D. B., Gregersen, P. L., and Thordal-Christensen, H. 1994. The induction of gene expression in response to pathogenic microbes. Pages 391-433 in: Mechanisms of Plant Growth and Improved Productivity: Modern Approaches and Perspectives. A. S. Basra, ed. Marcel Dekker, New York.

Cordier, C., Gianinazzi, S., and Gianinazzi-Pearson, V. 1996. Colonisation patterns of root tissues by Phytophthora nicotianae var. parasitica related to reduced disease in mycorrhizal tomato. Plant Soil 185: 223-232.

Daft, M. J., and Okusanya, B. O. 1973. Effect of Endogone mycorrhiza on plant growth. New Phytol. 72:1333-1339.

Davis, R. M., and Menge, J. A. 1980. Influence of Glomus fasciculatus and soil phosphorus on Phytophthora root rot of citrus. Phytopathology 70:447-452.

Dehne, H. W., and Schönbeck, F. 1979. The influence of endotrophic mycorrhiza on plant diseases. II. Phenol metabolism and lignification. Phytopathol. Z. 95:210-216.

Falk, S. P., Pearson, R. C., Gadoury, D. M., Seem, R. C., and Sztejnberg, A. 1996. Fusarium proliferatum as a biocontrol agent against grape downy mildew. Phytopathology 86:1010-1017.

Feder, N., and O'Brien, T. P. 1968. Plant microtechnique: Some principles and new methods. Am. J. Bot. 55:123-142.

Fernandez, M. R., and Heath, M. C. 1986. Cytological responses induced by five phytopathogenic fungi in a nonhost plant Phaseolus vulgaris. Can. J. Bot. 64:648-657.

Gianinazzi, S. 1991. Vesicular-arbuscular (endo-)mycorrhizas: Cellular, biochemical and genetic aspects. Agric. Ecosyst. Environ. 35:105111.

Gianinazzi, S., and Gianinazzi-Pearson, V. 1992. Cytology, histochemistry and immunocytochemistry as tools for studying structure and function in endomycorrhiza. Methods Microbiol. 24:109-139.

Gianinazzi-Pearson, V. 1996. Plant cell responses to arbuscular mycorrhizal fungi: Getting to the roots of the symbiosis. Plant Cell 8:
1871-1883.

Gianinazzi-Pearson, V., Gollotte, A., Lherminier, J., Tisserant, B., Franken, P., Dumas-Gaudot, E., Lemoine, M. C., van Tuinen, D., and Gianinazzi, S. 1995. Cellular and molecular approaches in the characterization of symbiotic events in functional arbuscular mycorrhizal associations. Can. J. Bot. 73:S526-S532.

Gianinazzi-Pearson, V., Tahiri-Alaoui, A., Antoniw, J. F., Gianinazzi, S., and Dumas-Gaudot, E. 1992. Weak expression of the pathogenesisrelated PR-b1 gene and localization of related proteins during symbiotic endomycorrhizal interactions in tobacco roots. Endocyt. Cell Res. $8: 177-185$

Gollotte, A., Cordier, C., Lemoine, M. C., and Gianinazzi-Pearson, V. 1997. Role of fungal wall components in interactions between endomycorrhizal symbionts. Pages 412-428 in: Eukaryotism and Symbiosis. H. E. A. Schenck, R. Herrmann, K. W. Jeon, N. E. Müller, and W. Schwemmler, eds. Springer-Verlag, Berlin.

Gollotte, A., Gianinazzi-Pearson, V., and Gianinazzi, S. 1994. Etudes immunocytochimiques des interfaces plante-champignon endomycorhizien à arbuscules chez des pois isogéniques $\mathrm{myc}^{+}$ou résistant à l'endomycorhization $\left(\mathrm{myc}^{-}\right)$. Acta Bot. Gall. 141:449-454.

Graham, J. H., and Menge, J. A. 1982. Influence of vesicular-arbuscular mycorrhizae and soil phosphorus on take-all disease of wheat. Phytopathology 72:95-98.

Guillemin, J. P., Gianinazzi, S., Gianinazzi-Pearson, V., and Marchal, J. 1994. Contribution of arbuscular-mycorrhizas to biological protection of micropropagated pineapple (Ananas comosus (L.) Merr) against $P$. cinnamomi rands. Agric. Sci. Finland 3:241-251.

Hahn, M. G., Bucheli, P., Cervone, F., Doares, S. H., O'Neill, R. A., Darvill, A., and Albersheim, P. 1989. Roles of cell wall constituents in plant-pathogen interactions. Pages 131-181 in: Plant-Microbe Interactions: Molecular and Genetic Perspectives. Vol 3. T. Kosuge and E. W. Nester, eds. Macmillan, New York.

Hammond-Kosack, K. E., and Jones, J. D. G. 1996. Resistance genedependent plant defense responses. Plant Cell 8:1773-1791.

Handelsman, J., and Stabb, E. V. 1996. Biocontrol of soilborne plant pathogens. Plant Cell 8:1855-1869.

Harrison, M. J., and Dixon, R. A. 1994. Spatial patterns of expression of flavonoid/isoflavonoid pathway genes during interactions between roots of Medicago truncatula and the mycorrhizal fungus Glomus versiforme. Plant J. 6:9-20.

Hoffland, E., Hakulinen, J., and van Pelt, J. A. 1996. Comparison of systemic resistance induced by avirulent and nonpathogenic Pseudomonas species. Phytopathology 86:757-762.

Hooker, J. E., Jaizme-Vega, M., and Atkinson, D. 1994. Biocontrol of plant pathogens using arbuscular mycorrhizal fungi. Pages 191-200 in: Impact of Arbuscular Mycorrhizas on Sustainable Agriculture and Natural Ecosystems. S. Gianinazzi and H. Schüepp, eds. Birkhäuser Verlag, Basel, Switzerland.

Jahnen, W., and Hahlbrock, K. 1988. Cellular localization of nonhost resistance reactions of parsley (Petroselinum crispum) to fungal infection. Planta 173:197-204.

Jalali, B. L., and Jalali, I. 1991. Mycorrhiza in plant disease control. Pages 131-154 in: Handbook of Applied Mycology. Vol. 1. Soil and Plants. D. K. Arora, B. Rai, K. G. Mukherjee, and D. Knudsen, eds. Marcel Dekker, New York.

Knox, J. P., Linstead. P. J., King, J., Cooper, C., and Roberts, K. 1990. Pectin esterification is spatially regulated both within cell walls and between developing tissues of root apices. Planta 181:512-521.

Lambais, M. R., and Mehdy, M. C. 1993. Suppression of endochitinase, $\beta-1,3$-endoglucanase and chalcone isomerase expression in bean vesicular-arbuscular mycorrhizal roots under different soil phosphate conditions. Mol. Plant-Microbe Interact. 6:75-83.

Larkin, R. P., Hopkins, D. L., and Martin, F. N. 1996. Suppression of Fusarium wilt of watermelon by nonpathogenic Fusarium oxysporum and other microorganisms recovered from a disease-suppressive soil. Phytopathology 86:812-819.

Lemanceau, P., and Alabouvette, C. 1993. Suppression of Fusarium wilts by fluorescent pseudomonas. Mechanisms and applications. Biocont. Sci. Technol. 3:219-234.

Linderman, R. G. 1994. Role of VAM fungi in biocontrol. Pages 1-25 in: Mycorrhizae and Plant Health. F. L. Pfleger and R. G. Linderman, eds. American Phytopathological Society, St. Paul, MN.

Linthorst, H. G. M. 1991. Pathogenesis-related proteins in plants. Crit. Rev. Plant Sci. 10:123-150. 
Mark, G. L., and Cassells, A. C. 1996. Genotype-dependence in the interaction between Glomus fistulosum, Phytophthora fragariae and the wild strawberry (Fragaria vesca). Plant Soil 185:233-238.

Maurhofer, M., Hase, C., Meuwly, P., Métraux, J.-P., and Défago, G. 1994. Induction of systemic resistance of tobacco to tobacco necrosis virus by the root-colonizing Pseudomonas fluorescens strain CHAO: Influence of the gacA gene and of pyoverdine production. Phytopathology 84:139-146.

Morandi, D. 1996. Occurrence of phytoalexins and phenolic compounds in endomycorrhizal interactions, and their potential role in biological control. Plant Soil 185:241-251.

Niderman, T., Genetet, I., Bruyere, T., Gees, R., Stintzi, A., Legrand, M., Fritig, B., and Mösinger, E. 1995. Pathogenesis-related PR-1 proteins are antifungal. Plant Physiol. 108:17-27.

Park, K. S., Moyne, A. L., Tuzun, S., Kim, C. H., and Kloepper, J. W. 1997. Induction of PR-1a promoter in a transgenic tobacco reporter system by selected PGPR strains which induce resistance. Pages 251255 in: Plant Growth-Promoting Bacteria: Present Status and Future Prospects. A. Ogoshi, K. Kobayashi, Y. Homma, F. Kodama, N. Kondo, and S. Akino, eds. Nakanishi Printing, Sapporo, Japan.

Phillips, J. M., and Hayman, D. S. 1970. Improved procedures for cleaving and staining parasitic and vesicular-arbuscular mycorrhizal fungi for rapid assessment of infection. Trans. Br. Mycol. Soc. 55: 158-161.

Pozo, M. J., Dumas-Gaudot, E., Slezack, S., Cordier, C., Asselin, A., Gianinazzi, S., Gianinazzi-Pearson, V., Azcon-Aguilar, C., and Barea, J. M. 1996. Induction of new chitinase isoforms in tomato roots during interactions with Glomus mosseae and/or Phytophthora nicotianae var. parasitica. Agronomie 16:699-707.

Ricci, P., Trentin, F., Bonnet, P., Venard, P., Mouton-Perronnet, F., and Bruneteau, M. 1992. Differential production of parasiticein, an elicitor of necrosis and resistance in tobacco, by isolates of Phytophthora parasitica. Plant Pathol. 41:298-307.

Rodriguez-Galvez, E., and Mendgen, K. 1995. Cell wall synthesis in cotton roots after infection with Fusarium oxysporum. Planta 197: 535-545.

Rosendahl, S. 1985. Interactions between the vesicular-arbuscular my- corrhizal fungus Glomus fasciculatum and Aphanomyces euteiches root rot of peas. Phytopathol. Z. 114:31-40.

Ryals, J. A., Neuenschwander, U. M., Willts, M. G., Molina, A., Steiner, H. Y., and Hunt, M. D. 1996. Systemic acquired resistance. Plant Cell 8:1809-1819.

Skalamera, D., and Heath, M. C. 1996. Cellular mechanisms of callose deposition in response to fungal infection or chemical damage. Can. J. Bot. 74:1236-1242.

Tahiri-Alaoui, A., Dumas-Gaudot, E., and Gianinazzi, S. 1993. Immunocytochemical localization of pathogenesis-related PR1 proteins in tobacco root tissues infected in vitro by the black root rot fungus Chalara elegans. Physiol. Mol. Plant Pathol. 42:69-82.

Thiery, J. P. 1967. Mise en évidence des polysaccharides sur coupes fines en microscopie éléctronique. J. Microsc. (Paris) 6:987-1018.

Thomashow, L. S., and Weller, D. M. 1995. Current concepts in the use of introduced bacteria for biological control: mechanisms and antifungal metabolites. Pages 187-235 in: Plant-Microbe Interactions. Vol 1. G. Stacey and N. Keen, eds. Chapman and Hall, New York.

Trotta, A., Vanese, G. C., Gnavi, E., Fusconi, A., Sampo, S., and Berta, G. 1996. Interactions between the soilborne root pathogen Phytophthora nicotianae var. parasitica and the arbuscular mycorrhizal fungus Glomus mosseae in tomato plants. Plant Soil 185:199-209.

Trouvelot, A., Kough, J. L., and Gianinazzi-Pearson, V. 1986. Mesure du taux de mycorhization VA d'un système radiculaire. Recherche de méthodes d'estimation ayant une signification fonctionnelle. Pages 217-221 in: Physiological and Genetical Aspects of Mycorrhizae. V. Gianinazzi-Pearson and S. Gianinazzi, eds. INRA, Paris.

Van Peer, R., Niemann, G. J., and Schippers, B. 1991. Induced resistance and phytoalexin accumulation in biological control of Fusarium wilt of carnation by Pseudomonas sp. strain WCS 417r. Phytopathology 81:728-734.

Van Wees, S. C. M., Pieterse, C. M. J., Trijssenaar, A., Van't Westende, Y. A. M., Hartog, F., and Van Loon, L. C. 1997. Differential induction of systemic resistance in Arabidopsis by biocontrol bacteria. Mol. Plant-Microbe Interact. 10:716-724.

Weller, D. M. 1988. Biological control of soilborne plant pathogens in the rhizosphere with bacteria. Annu. Rev. Phytopathol. 26:379-407. 